\title{
STUDY ON THE OXYGENATION VELOCITY OF THE HUMAN RED CELL
}

\author{
Masaji MochizukI \\ Research Institute of Applied Electricity, \\ Hokkaido University, Sapporo
}

As described in the preceding paper ${ }^{1)}$, HARTRIDGE and ROUGHTON ${ }^{2)}$ clarified in 1926 that the oxygenation velocity of the red cell was much slower than that of $\mathrm{Hb}$ solution. Then RoughtoN and NICOLSON ${ }^{3,4,5)}$ studied theoretically the relation between the $\mathrm{O}_{2}$ diffusion inside the red cell and the oxygenation. However, the data which were valuable to consider the relationship between the oxygenation velocity of the red cell and the pulmonary diffusing capacity were not obtained before 1955. In that year GIBSON and others ${ }^{6)}$ measured the oxygenation velocity of the red cell using the human red cell at $37^{\circ} \mathrm{C}$. While SIRS and Roughton ${ }^{7}$ (1963) advanced this study further, using a stopped flow method instead of the rapid flow. Still, however, the oxygenation velocity in the range of $\mathrm{S}_{\mathrm{O}_{2}}$ from 70 to $100 \%$ had not been measured until quite recently.

In 1961 STAUB and others ${ }^{8)}$ measured the oxygenation of the human red cell by using a Pt electrode instead of the conventional photometric method. They measured the velocity all over the range from 0 to $95 \%$ of $\mathrm{S}_{\mathrm{O}_{2}}$, but the variation of the measured values was so large, that there remained an additional problem, whether the variation was inherent to the individual subject or was it only the error of the measurements.

Different from $\mathrm{Hb}$, the red cell scatters the incident light. Therefore, it is fairly difficult to find a change in light absorption due to oxygenation in red cell suspension. When the suspension is made to flow through an observation tube, the amount of the scattered light depends on the flow velocity. Thus, a fluctuation appears on the photosignals, when the flow velocity is not constant. This is especially true, because the change in light absorption due to oxygenation is usually comparable to the noise due to the uneven velocity of flow; therefore, it is absolutely necessary to avoid the influence of light scattering. On the other hand, since the amount of the scattered light is indifferent to the wave length, the influence of it has so far been excluded by taking the difference of tranmissions at two wave lengths ${ }^{7,9,10)}$. In this

Received for publication February 19, 1966

* 望月政司 
study, too, an apparatus was newly built by using such a technique as mentioned above.

\section{METHOD}

The schematic diagram of the apparatus used is shown in FIG. 1. The practical procedures were almost the same as those described in the foregoing paper,1) apart from the following points.

1) Mixing chamber and the observation tube. As shown at the lower part of FIG. 1, the mixing chamber used in this study was a simple two jet chamber made of a $\mathrm{T}$ shaped glass tube. The entire portion for mixing had an inner diameter of $1 \mathrm{~mm}$. Two solutions from the syringes of $20 \mathrm{ml}$ were brought into a headon collision at a joint portion of the T-tube and mixed in a narrow space, $5 \mathrm{~mm}$ in length. Thus, in this apparatus the contact surface was fairly large in comparison with the volume of the mixing space. The flow velocity through the observation tube was $42 \mathrm{~cm}-\mathrm{sec}^{-1}$ in most cases.

The observation tube used was circular and its inner diameter was $3.5 \mathrm{~mm}$, as shown on the left side of FIG. 1. In order to increase the signal to noise ratio, the tube was fixed in a brass block which had a slit of $1 \mathrm{~mm}$ in width across the light path. The block was heated up to $37^{\circ} \mathrm{C}$ by a heater. The photometric assembly was so constructed

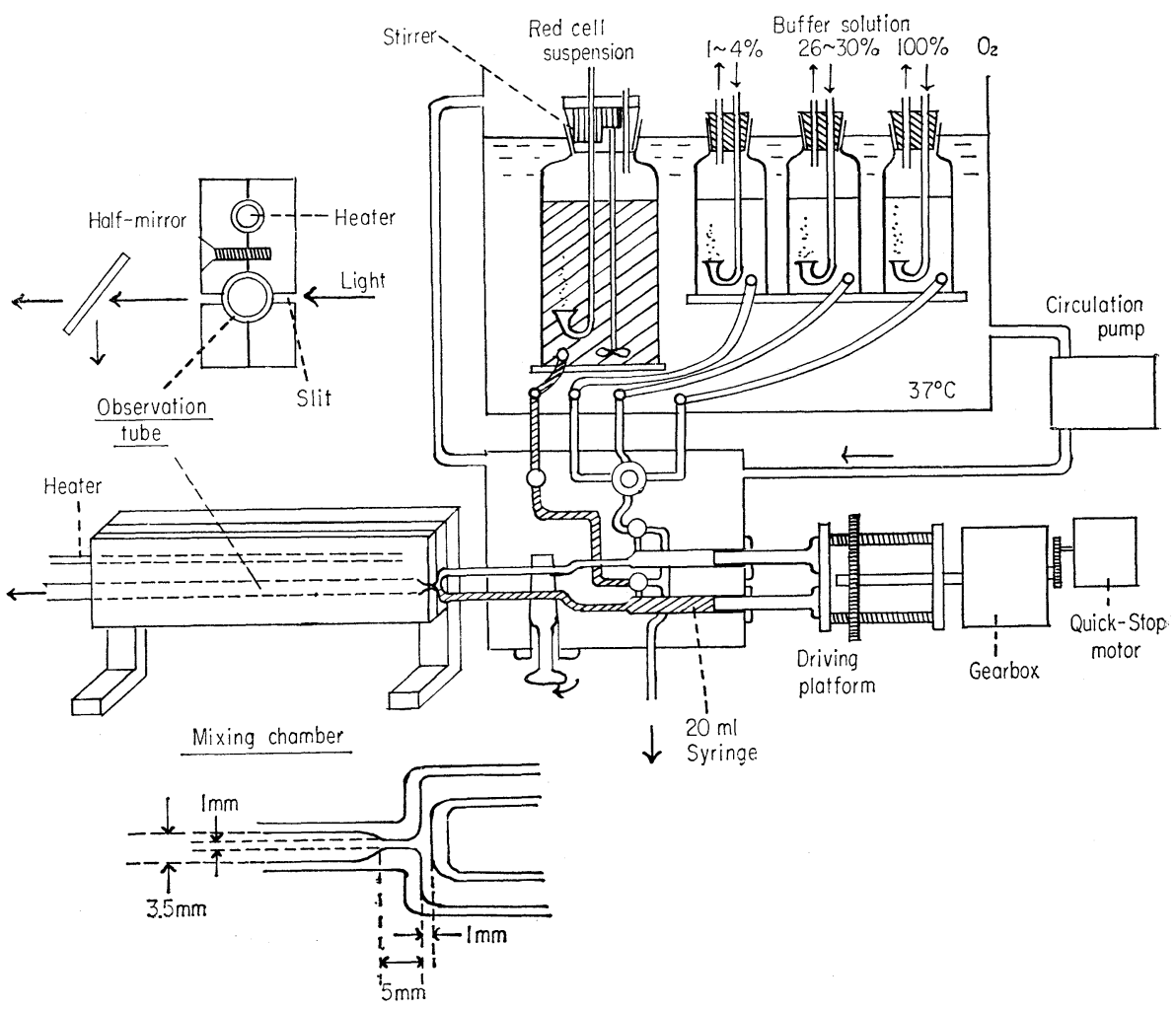

FIG. 1. Schematic illustration of the whole arrangement. 
as to be moved along the observation tube on a solid truck.

2) Photometry. Transmitted light intensities were measured at two wave lengths of 572 and 599 milli-micron, as shown in FIG. 2. The light going across the observation tube was divided into two parts by a neutral half-mirror, and then each part was made to pass through their respective interference filter to a photomultiplier. Both photosignals from the photomultipliers were further amplified by a differential amplifier and then recorded on a pen recorder.

3) Solutions and gases. The red cell suspension was prepared by adding whole blood of $5 \mathrm{ml}$ into 2 liters of a phosphate buffer solution. Before each measurement the blood sample was drawn freshly and heparinized. The buffer solution was composed of $\mathrm{NaCl}$ $7.88 \mathrm{~g}, \mathrm{KCl} 0.26 \mathrm{~g}, \mathrm{KH}_{2} \mathrm{PO}_{4} 3 \mathrm{mg}, \mathrm{Na}_{2} \mathrm{HPO}_{4} 0.85 \mathrm{~g}, \mathrm{NaHOC}_{3} 2.4 \mathrm{~g}$ and distilled water $1.000 \mathrm{ml}$. $\mathrm{pH}$ of the solution was about 7.40 at $\mathrm{P}_{\mathrm{CO}_{2}} 40 \mathrm{mmHg}$.

Three kinds of mixed gases were used for tonometry; their compositions were as follows: 1) $\mathrm{P}_{\mathrm{O}_{3}}$ ranging from 180 to $220 \mathrm{mmHg}$ and $\mathrm{P}_{\mathrm{CO}_{2}} 40$ to $\left.60 \mathrm{mmHg}, 2\right) \mathrm{P}_{\mathrm{O}_{2}} 4$ to $40 \mathrm{mmHg}$ and $\mathrm{P}_{\mathrm{CO}_{3}} 40$ to $60 \mathrm{mmHg}$ and 3) pure $\mathrm{O}_{2}$. The pure $\mathrm{O}_{2}$ was used to obtain the full oxygenated $\mathrm{S}_{\mathrm{O}_{2}}$ level, that is, the full oxygenated suspension was made by mixing the red cell suspension of low $\mathrm{P}_{\mathrm{O}_{2}}$ with the buffer solution bubbled with pure $\mathrm{O}_{2}$. Since the oxygenation proceeds very rapid at a hyperoxic level over $300 \mathrm{mmHg}$, the full saturated level can be attained easily through this method. When the reaction time is very short, the $\mathrm{S}_{\mathrm{O}_{2}}$ is still lower than $100 \%$. For getting a reliable level for $100 \% \mathrm{~S}_{\mathrm{O}_{2}}$ however, this method was much better than the one in which the suspension of
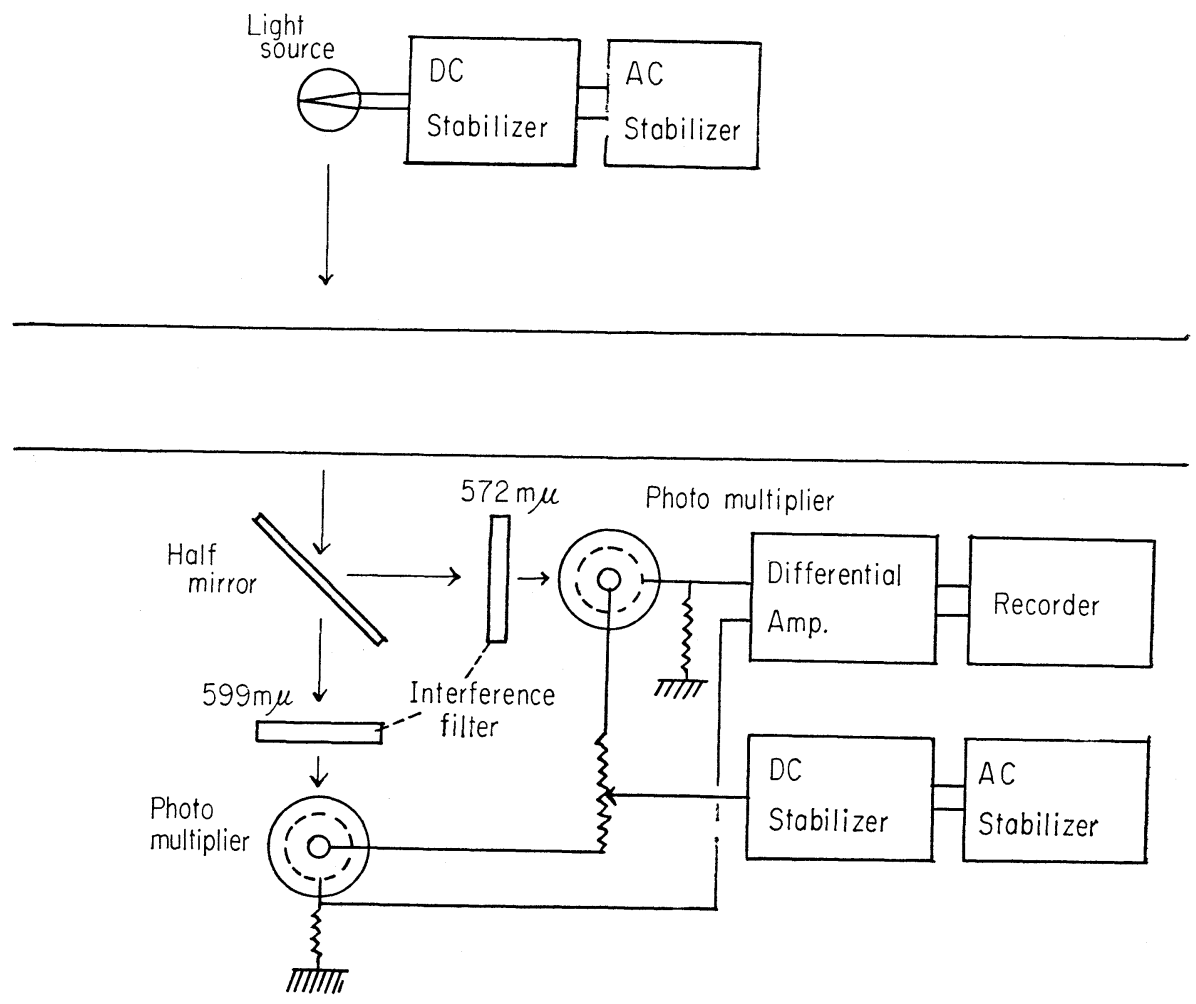

Fig. 2. Block diagram of the photometric apparatus. 
TABLE 1. Composition of mixed gases used for tonometry.

\begin{tabular}{|c|c|c|c|c|c|c|}
\hline \multirow{2}{*}{ No. } & \multirow{2}{*}{$\begin{array}{l}\text { Number of } \\
\text { Subjects }\end{array}$} & \multirow{2}{*}{ Date } & \multicolumn{2}{|c|}{$\underset{(\mathrm{mmHg})}{\mathrm{High} \mathrm{O}_{2} \text { gas }}$} & \multicolumn{2}{|c|}{$\begin{array}{c}\text { Low } \mathrm{O}_{2} \text { gas } \\
(\mathrm{mmHg})\end{array}$} \\
\hline & & & $\mathrm{P}_{\mathrm{O}_{2}}$ & $\mathrm{P}_{\mathrm{CO}_{2}}$ & $\mathrm{P}_{\mathrm{O}_{2}}$ & $\mathrm{P}_{\mathrm{CO}_{2}}$ \\
\hline 1 & 2 & May, $13-14$ & 231 & 50 & 26 & 37 \\
\hline 2 & 2 & May, $15-17$ & 200 & 29 & 29 & 37 \\
\hline 3 & 3 & May, 17-19 & 200 & 29 & 29 & 37 \\
\hline 4 & 2 & June, 21-23 & 185 & 47 & 9 & 55 \\
\hline 5 & 1 & June, 23 & 185 & 47 & 24 & 74 \\
\hline 6 & 4 & June, $24-25$ & 205 & 40 & 9 & 55 \\
\hline 7 & 4 & June, 29-30 & 205 & 40 & 24 & 74 \\
\hline 8 & 2 & July, $\quad 5-6$ & 205 & 40 & 29 & 56 \\
\hline
\end{tabular}

$100 \% \mathrm{SO}_{2}$ was additionally prepared as the standard suspension for the calibration, for the concentration of the red cell easily varied to a large extent in the red cell suspension.

The compositions of the high and low $\mathrm{O}_{2}$ groups of the mixed gases used are tabulated in TABLE 1.

\section{RESULTS}

The oxygenation velocity was measured in 7 cases of different $\mathrm{P}_{\mathrm{O}_{2}}$ and $\mathrm{P}_{\mathrm{CO}_{2}}$ with samples collected from normal 7 subjects, as shown in TABLE 1 . In the experiments of No. 2 and 3 , the day by day variation was examined with the same subjects under the same experimental conditions. The recorded curves shown in FIg. 3 obtained in the experiment No. 8. As shown in this figure duplicate measurements were carried out at three levels of $\mathrm{S}_{\mathrm{O}_{2}}$, i. e. initial $\mathrm{S}_{\mathrm{O}_{3}}$, the full oxygenated $\mathrm{S}_{\mathrm{O}_{2}}$ and the changing $\mathrm{S}_{\mathrm{O}_{2}}$ between the two. The initial $\mathrm{S}_{\mathrm{O}_{2}}$ of the experiment No. 8 was $57.5 \%$; this figure was determined by referring to the initial $\mathrm{P}_{\mathrm{O}_{2}}$ and the $\mathrm{O}_{2}$ dissociation curve of blood. The error of the duplicate measurements was within $1 \%$ in $\mathrm{S}_{\mathrm{O}_{3}}$.

In FIG. 4 are shown the changes of $\mathrm{S}_{\mathrm{O}_{2}}$ along the reaction time which were measured in the experiment No. 6. The plotted points are the mean values of 4 different subjects and the arrows illustrated at the points represent standard deviations around the mean. The standard deviations were about $2.5 \%$ in $\mathrm{S}_{2}$ in the case of the experiment No. 6 and $1.3 \%$ in the case of No. 7. As seen in TABLE $1, \mathrm{P}_{\mathrm{O}_{2}}$ and $\mathrm{P}_{\mathrm{CO}_{2}}$ of the original red cell suspension was 9 and $55 \mathrm{mmHg}$ and those of the buffer solution were 205 and $40 \mathrm{mmHg}$. Thus, when they were mixed with the equal amount to each other, the initial $\mathrm{P}_{\mathrm{O}_{2}}$ of the solution surrounding the red cell should be $107 \mathrm{mmHg}$ and the $\mathrm{P}_{\mathrm{CO}_{2} \text {, }}$ $47 \mathrm{mmHg}$. It follows that the oxygen molecule should have diffused into the red cell and $\mathrm{CO}_{2}$ diffused out of the red cell. In the case of No. 7 the same type of diffusion should have occurred, for $\mathrm{P}_{\mathrm{CO}}$, of the buffer solution was 
higher than that of the initial red cell suspension. Consequently, the BoHR effect may be included in the oxygenation reactions which are represented by the curves in FIG. 4.

As described already, in the experiments No. 2 and 3 the $\mathrm{S}_{\mathrm{O}_{2}}$-time curves were measured duplicately on the same subjects under the same conditions of $\mathrm{P}_{\mathrm{O}_{2}}$ and $\mathrm{P}_{\mathrm{CO}}$, but on different days. The variations of the measured $\mathrm{S}_{\mathrm{O}_{2}}$ were similar to those observed in the experiments No. 6 and 7 . Therefore, the variations expressed by standard deviations seems to be due mainly to the measuring procedure, and not to the individual variation of the oxygenation velocity.

During the 4th experiment the oxygenation of $\mathrm{Hb}$ solution was also measured as shown in FIG. 5, for the purpose to determine the oxygenation velocity at $\mathrm{S}_{\mathrm{O}_{2}}$ range of more than $90 \%$ on one hand, and to check the mixing effect of the mixing chamber used on the other hand. The electrolyte composition of $\mathrm{Hb}$ solution was similar to the one described in the previous paper; except that $1.05 \mathrm{~g} \mathrm{NaHCO}_{3}$, instead of $2.40 \mathrm{~g}$, was added to $1 l$ of the buffer solution.
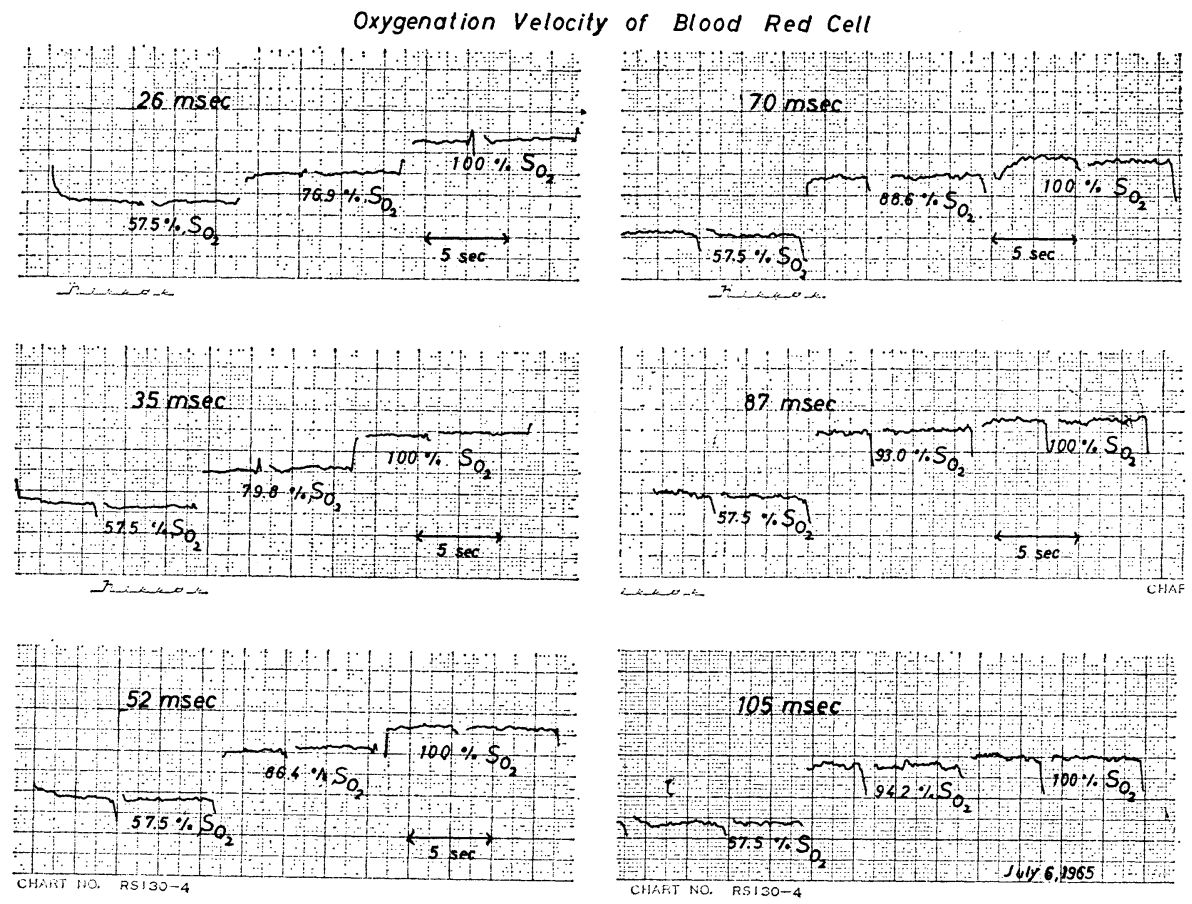

$$
\text { Sub: M.M. } \quad P_{\mathrm{CO}_{2}}=48 \mathrm{mmHg}, \mathrm{pH}=7.40, \quad 37^{\circ} \mathrm{C} .
$$

FIG. 3. Actual records of the light intensities at 6 different reaction times obtained in the No. 8 experiment. In each record the transmissions were measured at three levels of $\mathrm{S}_{2}$ i. e. $57.5 \%, 100 \%$ and the varying level of the mixed suspension. 
The $\mathrm{pH}$ of the solution was 7.26 at $40 \mathrm{mmHg} \mathrm{P}_{\mathrm{CO}_{2}}$. The $\mathrm{P}_{\mathrm{O}_{2}}$ and $\mathrm{P}_{\mathrm{CO}_{2}}$ of $\mathrm{Hb}$ solution were 9 and $55 \mathrm{mmHg}$ respectively. As the $\mathrm{P}_{\mathrm{O}_{2}}$ after mixing was comparatively high, the oxygenation occurred very fast, and $\mathrm{S}_{\mathrm{O}_{2}}$ reached $90 \%$ within $10 \mathrm{msec}$ after mixing. However, the oxygenation velocity from $90 \%$ to $100 \%$ were obviously slowed down; this tendency was observed also in the oxygenation process of the red cell.

In the experiment No. 4, the oxygenation of the red cell was observed at

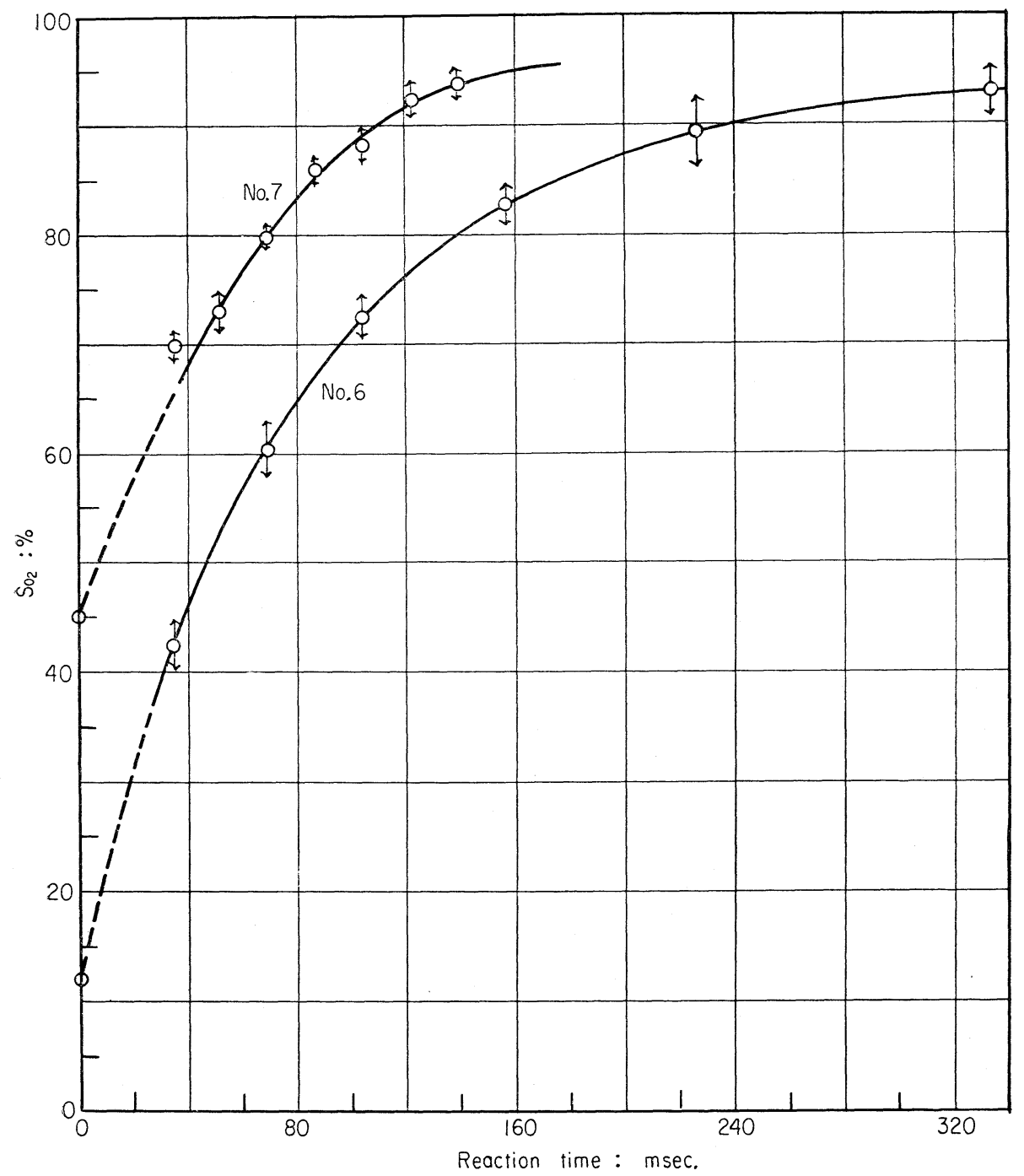

FIG. 4. Changes of $\mathrm{O}_{2}$ saturation, $\mathrm{S}_{\mathrm{O}_{2}}$, plotted against the reaction time obtained in the experiments of Nos. 6 and 7 . 
two levels of pH's of 7.40 and 6.85. In the latter case $\mathrm{NaHCO}_{3}$ was added to the solution in the concentration of $1.05 \mathrm{~g} \cdot 1^{-1}$ instead of $2.40 \mathrm{~g} \cdot 1^{-1}$, and thus its $\mathrm{pH}$ became 6.85 , while the $\mathrm{P}_{\mathrm{CO}_{2}}$ was the same in both cases. The closed circles in FIG. 5 represent the $\mathrm{S}_{\mathrm{O}_{2}}$ in the suspension of the $6.85 \mathrm{pH}$. As the affinity of the red cell for $\mathrm{O}_{2}$ is lowered in an acid solution, the terminal $\mathrm{S}_{\mathrm{O}_{2}}$ level was markedly low in the suspension of the low $\mathrm{pH}$ than that in the suspension of $\mathrm{pH} 7.46$. The oxygenation velocity from 10 to $60 \% \mathrm{~S}_{\mathrm{O}_{2}}$, however,

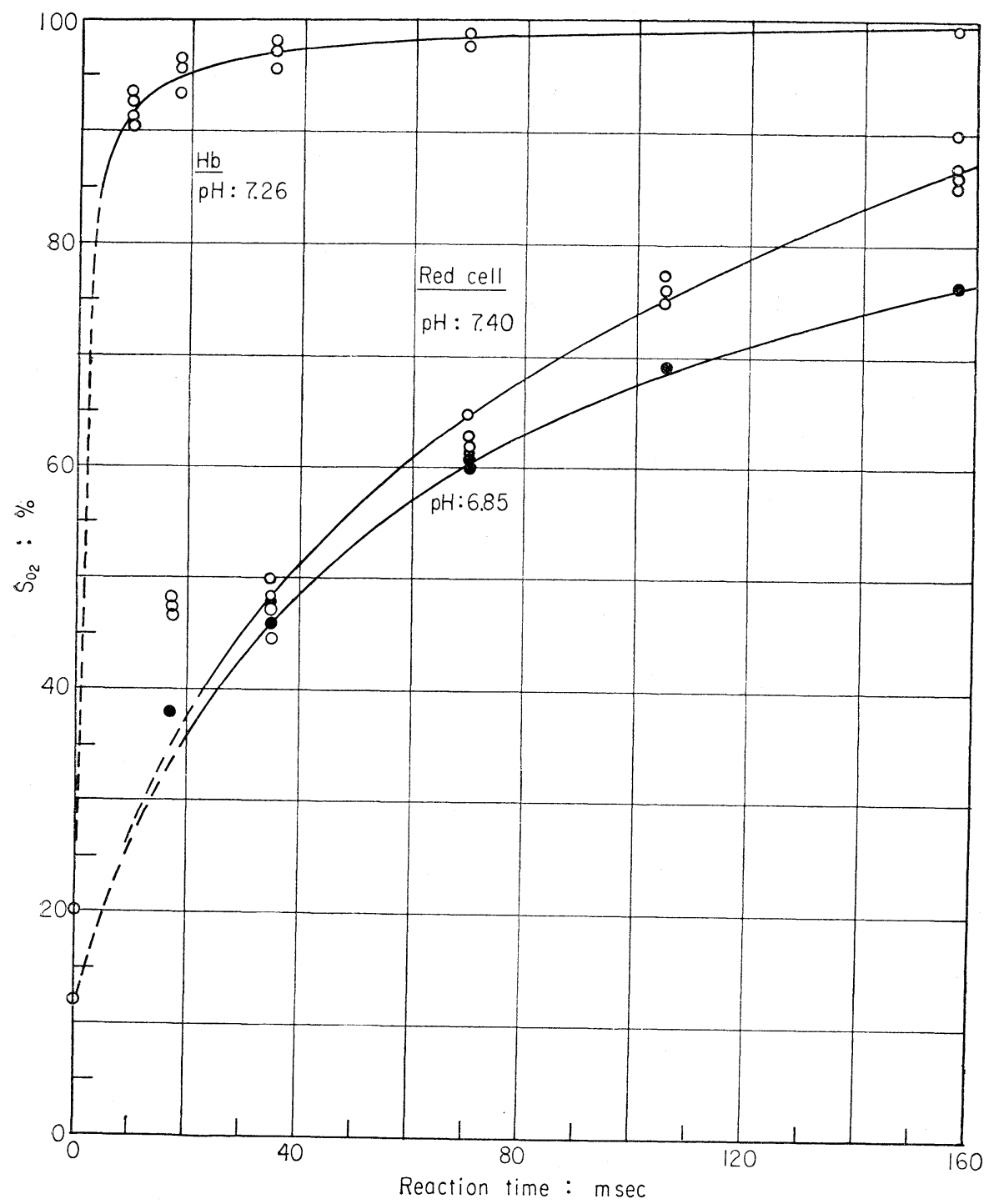

FIG. 5. Changes of $\mathrm{O}_{2}$ saturation, $\mathrm{S}_{\mathrm{O}_{2}}$ plotted against the reaction time obtained in red cell suspension of $\mathrm{pH} 7.40$ and 6.85 and in $\mathrm{Hb}$ solution of $\mathrm{pH} 7.26$. 
was of the same magnitude between the two kinds of suspension.

The plotted point at $18 \mathrm{msec}$ deviated largely upward from the smooth curve. This may be ascribed to the fact that the full oxygenated level could not be attained in such a short period as $18 \mathrm{msec}$ even at a hyperoxic level of more than $300 \mathrm{mmHg}$. In other words, the procedure to mix the buffer solution saturated with pure $\mathrm{O}_{2}$ and the red cell suspension of low $\mathrm{P}_{\mathrm{O}_{3}}$ seemed not to be satisfactory to obtain the full saturated suspension in such a short period.

As in the preceding paper ${ }^{1)}$, the oxygenation velocity was compared by values of the velocity factor, $F_{c}$. The values were calculated by dividing the $\mathrm{O}_{2}$ quantity taken up by $1 \mathrm{ml}$ red cells in a second by the $\mathrm{P}_{\mathrm{O}_{2}}$ difference between the red cell and the surrounding medium. Let the $\mathrm{P}_{\mathrm{O}_{3}}$ 's of the medium and the red cell be $\mathrm{P}$ and $\mathrm{P}_{c}$. The practical calculation was performed by the following formula, $\mathrm{P}_{\mathrm{c}}$ being estimated from the $\mathrm{O}_{2}$ dissociation curve of blood at $\mathrm{pH} 7.40$ by referring to the $\mathrm{S}_{\mathrm{O}}$ measured.

$$
\mathrm{F}_{\mathrm{c}}=\frac{0.4 \times 10^{-2} \mathrm{ds} / \mathrm{dt}}{\mathrm{P}-\mathrm{P}_{\mathrm{c}}},
$$

where $0.4 \times 10^{-2}$ represents the $\mathrm{O}_{2}$ combining capacity of $1 \mathrm{ml}$ of red cells versus $1 \%$ increase of $\mathrm{S}_{\mathrm{O}_{2}}$ and $\mathrm{dS} / \mathrm{dt}$ is the increasing rate of $\mathrm{S}_{\mathrm{O}_{2}}$ of the red cell.

The velocity factors, $F_{c}$, obtained during every $10 \mathrm{msec}$ along eight $\mathrm{So}_{\mathrm{O}_{2}}-$ time curves are shown in FIG. 6. The numbers written on the curves of

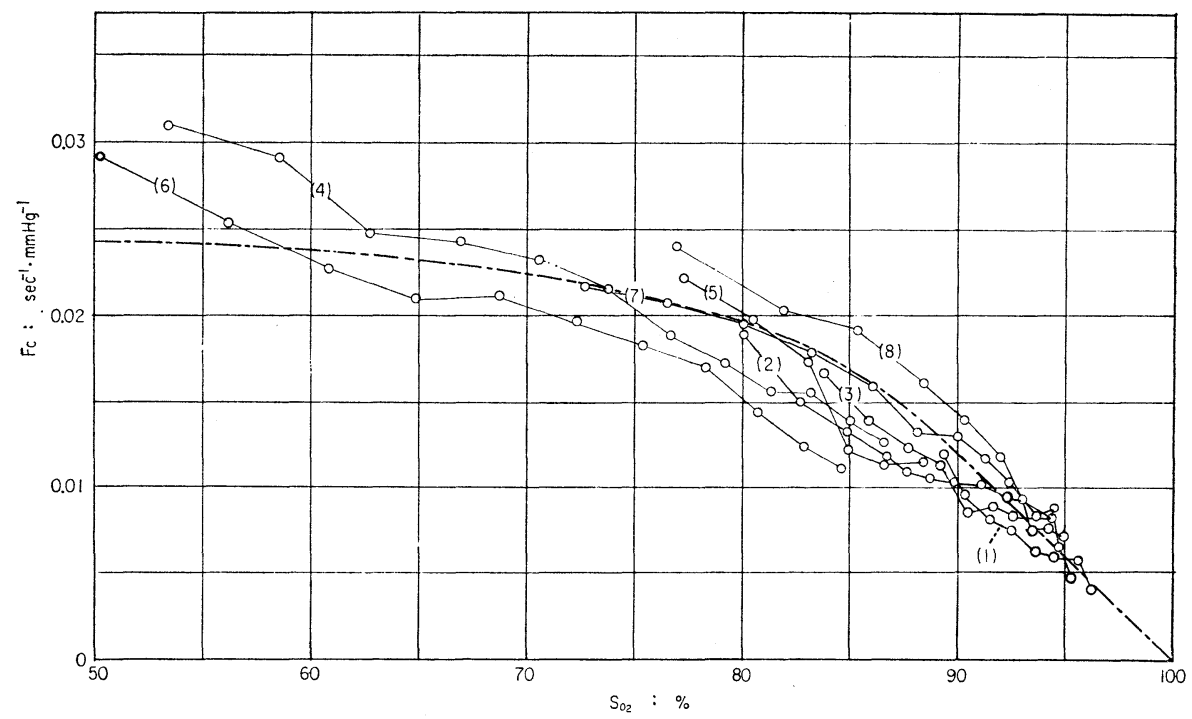

Fig. 6. Velocity factor of oxygenation of the red cell, $\mathrm{F}_{\mathrm{c}}$, plotted against the $\mathrm{O}_{2}$ saturation. The numbers noted on the curves are the experimental numbers shown in TABLE 1. 
FIG. 6 correspond to the experiment number shown in TABLE 1. Because $\theta$ derived by FORSTER and ROUGHTON ${ }^{11)}$ is the velocity factor expressed per one minute for the blood of $1 \mathrm{ml}$, it is about 30 times as great as $F_{c}$. As expected from the theoretical study the factor converged to $\mathrm{O}$ as the saturation proceeded. However, the measured values were about $2 / 3$ of the theoretical values obtained by the author ${ }^{12)}$ and about $1 / 3$ of the measured values reported by STAUB and others ${ }^{8)}$.

$\mathrm{P}_{\mathrm{CO}}$, of the red cell suspension and the buffer solution were ranged from 37 to $74 \mathrm{mmHg}$. However, $\mathrm{P}_{c}$ was estimated always by use of the $\mathrm{O}_{2}$ dissociation curve of $\mathrm{pH} 7.40$. Therefore, the error due to the variation of the

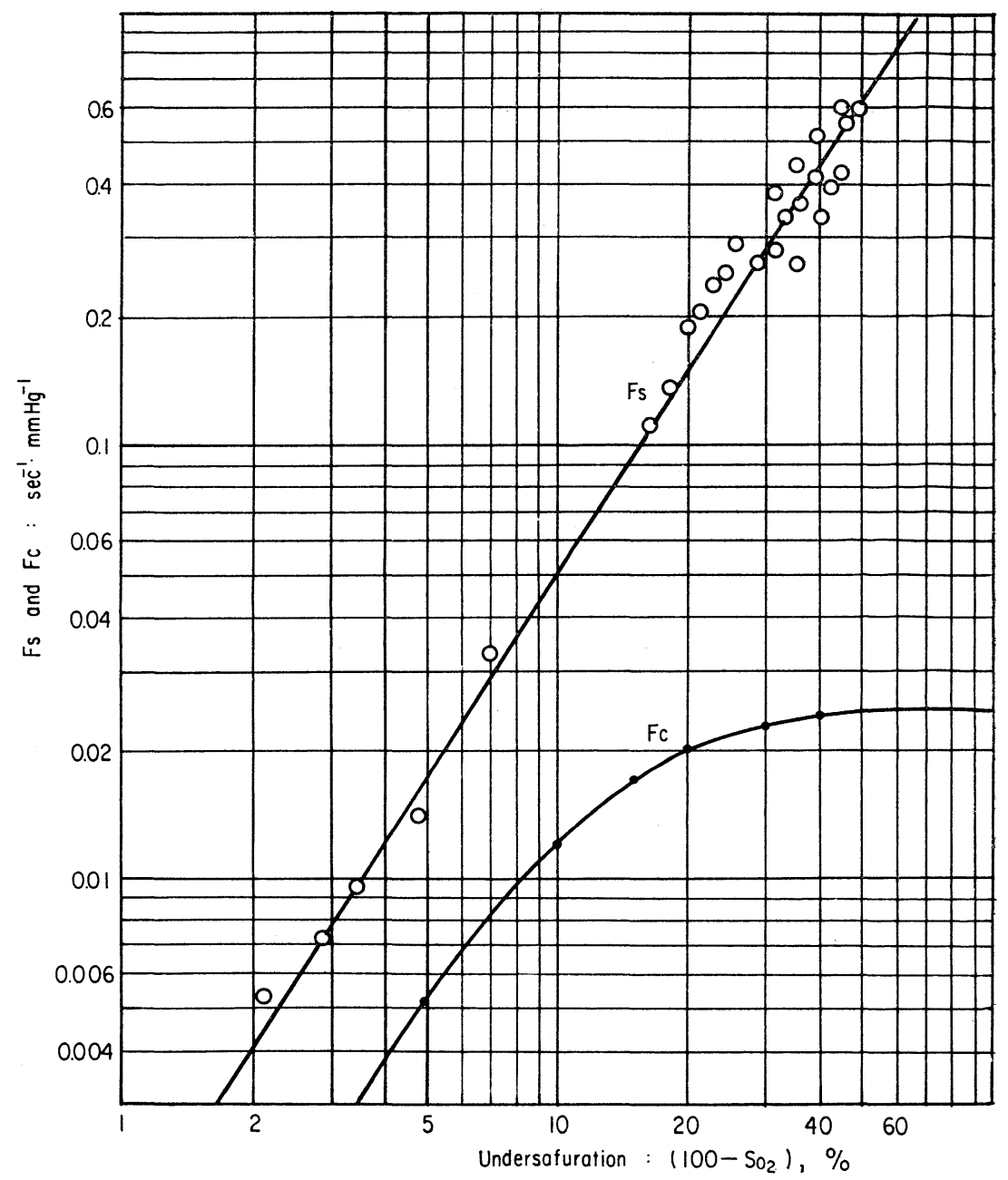

FIG. 7. Relationship between the velocity factors of the red cell, $\mathrm{F}_{\mathrm{c}}$, and the $\mathrm{Hb}$ solution, $\mathrm{F}_{\mathrm{S}}$, and the $\mathrm{O}_{2}$ undersaturation $\left(100-\mathrm{S}_{2}\right)$. 
dissociation curve is certainly implied in the calculation of the velocity factor.

The velocity factor of $\mathrm{Hb}, \mathrm{F}_{\mathrm{s}}$, was also calculated through the same procedure as $\mathrm{Eq}(1)$. In FIG. $7, \mathrm{~F}_{\mathrm{s}}$ are plotted together with the mean values of $F_{c}$ versus the undersaturation on a logarithmic graph. $F_{s}$ values at the lower $\mathrm{SO}_{2}$ range were rewritten from the preceding paper $^{11}$. The logarithm of $\mathrm{F}_{\mathrm{s}}$ was linear against that of the undersaturation as expressed experimentally by

$$
\mathrm{F}_{\mathrm{s}}=0.00106\left(100-\mathrm{S}_{\mathrm{O}_{2}}\right)^{1.6} \text {. }
$$

$\mathrm{Eq}(2)$ shows that $\mathrm{F}_{\mathrm{s}}$ had a non-linear relation to the undersaturation. Using the values of $F_{s}$ given by this equation, the $F_{c}$ values of FIG. 7 which were derived by a curve fitting method were expressed as follows:

$$
\mathrm{F}_{\mathrm{c}}=\frac{0.025 \times \mathrm{F}_{\mathrm{s}}{ }^{1.26}}{0.025 \times \mathrm{F}_{\mathrm{s}}{ }^{1.26}} \text {. }
$$

The broken line illustrated in FIG. 6 shows the curve given by $\mathrm{Eq}(3)$.

\section{DISCUSSION}

The non-linear relation of $F_{s}$ to the undersaturation was confirmed in this study as well as in the preceding paper. As the velocity factor means the velocity of the transfer or the conductivity of $\mathrm{O}_{2}$ from solution to $\mathrm{Hb}$ in the red cell, the reciprocal of the factor should indicate the resistance to the oxygenation. The reciprocal of $F_{c}$ is expressed from $\mathrm{Eq}(3)$ as

$$
1 / \mathrm{F}_{\mathrm{c}}=1 / 0.025+1 / \mathrm{F}_{\mathrm{s}}{ }^{1.26} \text {. }
$$

The total residence to the oxygenation of $\mathrm{Hb}$ in the red cell may, thus, be considered to be given by the sum of both the resistances to the diffusion and the chemical reaction. The resistance to the diffusion should be independent of the $\mathrm{S}_{\mathrm{O}_{2}}$, therefore, the first term of $\mathrm{Eq}(4)$ seems to indicate the resistance to the diffusion and the second term, that to the combination reaction of $\mathrm{O}_{2}$ and $\mathrm{Hb}$ in the red cell. As shown in FIG. 7, $\mathrm{F}_{\mathrm{s}}$ is smaller than the unity, hence, $F_{s}{ }^{1.26}$ is smaller than $F_{s}$ itself. This leads to the conclusion that the oxygenation velocity of $\mathrm{Hb}$ is slower in the red cell than in the laked $\mathrm{Hb}$ solution.

THEWS ${ }^{12213)}$ stated that the oxygenation velocity of the red cell was limited only by the diffusion, because the chemical reaction of $\mathrm{Hb}$ was very fast. Certainly the oxygenation of $\mathrm{Hb}$ occurs very fast in the $\mathrm{S}_{\mathrm{O}_{2}}$ range of $\mathrm{O}$ to $50 \%$, but in the upper $\mathrm{S}_{\mathrm{O}}$, range, above $70 \%$, the velocity turns slow. Hence his treatment will not hold for the oxygenation of the range over $70 \%$.

The relation of $\mathrm{F}_{\mathrm{c}}$ to $\mathrm{S}_{\mathrm{O}}$ is very important when considering the relationship of $F_{c}$ to the red cell component of the pulmonary diffusing capacity, $D_{B}$. BoHR ${ }^{15)}$ introduced an integral method to calculate the average $\mathrm{P}_{\mathrm{O}_{3}}$ of the capillary blood of the lung. In his theory, he took account of only the diffusion 
rate through the alveolar membrane and he assumed the diffusion rate always constant or indifferent to the back pressure, $\mathrm{P}_{\mathrm{c}}$. However, the oxygenation velocity is neither so rapid as to be disregarded nor it is independent of $P_{c}$. In FIG. 8 is illustrated the dependency of $F_{c}$ upon the back pressure on a semi-logarithmic graph. The line in this figure was obtained from the $F_{c}$

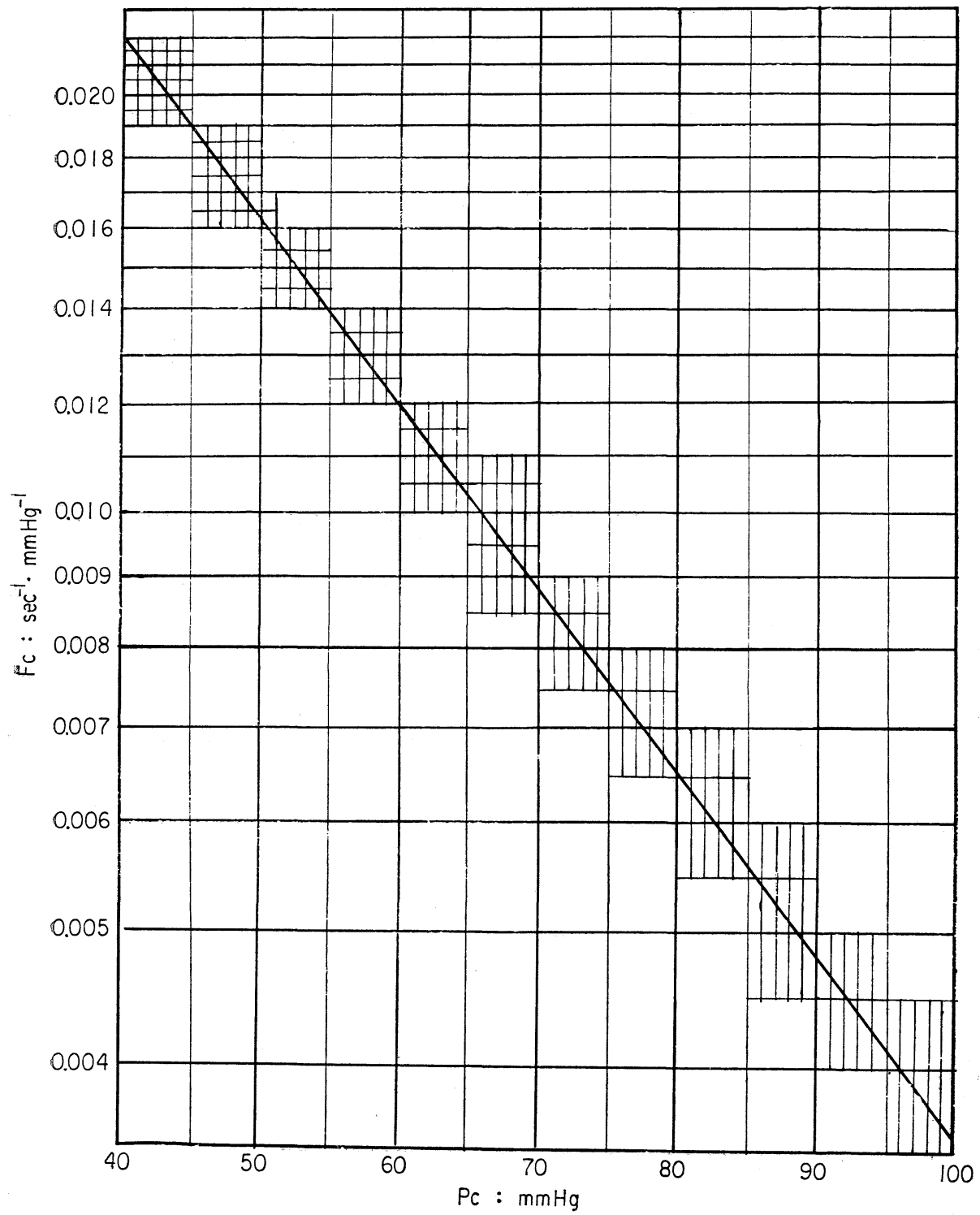

FIG. 8. Velocity factor of the red cell, $F_{c}$, plotted against the back pressure, $P_{c}$, which was obtained from the $\mathrm{O}_{2}$ saturation by referring to the $\mathrm{O}_{2}$ dissociation curve. 
curve in FIG. 7 by converting the undersaturation into the back pressure, $\mathrm{P}_{\mathrm{c}}$. As shown in FIG. 8, the logarithm of $F_{c}$ was obviously linear against $P_{c}$ over the $\mathrm{P}_{\mathrm{O}_{2}}$ range of 40 to $100 \mathrm{mmHg}$. Therefore, there are two problems concerning BoHR's integral method: one is, what the average $\mathrm{P}_{\mathrm{O}_{2}}$ obtained by his method means, and the other is whether or not the red cell component of the diffusing capacity, $D_{B}$, can be estimated by use of the relation of $F_{c}$ and $\mathrm{P}_{\mathrm{c}}$ shown in FIG. 8.

Suppose that $1 \mathrm{ml}$ of red cells are travelling through the alveolar gas phase with $\mathrm{O}_{2}$ tension, $\mathrm{P}_{\mathrm{A}}$. When the contact time, $\mathrm{T}_{\mathrm{c}}$, is divided into $\mathrm{n}$ time intervals, there are derived the following relations in the individual intervals similarly to $\mathrm{Eq}(1)$ :

$$
\begin{aligned}
& \frac{\Delta \mathrm{C}_{1}}{\mathrm{P}_{\mathrm{A}}-\mathrm{P}_{1}}=\mathrm{F}_{1} \Delta \mathrm{t}, \\
& \frac{\Delta \mathrm{C}_{2}}{\mathrm{P}_{\mathrm{A}}-\mathrm{P}_{2}}=\mathrm{F}_{2} \Delta \mathrm{t}, \\
& \cdots \cdots \cdots \cdots \cdots \cdots, \\
& \frac{\Delta \mathrm{C}_{\mathrm{n}}}{\mathrm{P}_{\mathrm{A}}-\mathrm{P}_{\mathrm{n}}}=\mathrm{F}_{\mathrm{n}} \Delta \mathrm{t},
\end{aligned}
$$

where $\Delta \mathrm{C}_{\mathrm{i}}, \mathrm{P}_{\mathrm{i}}$ and $\mathrm{F}_{\mathrm{i}}$ are the change of $\mathrm{O}_{2}$ content in $1 \mathrm{ml}$ red cells, the back pressure and the velocity factor of the red cell.

According to BoHR the sum of the $n$ left hand terms, $\sum_{0}^{n} C_{i} /\left(P_{A}-P_{i}\right)$, can be obtained by planimetry of the area, in which the abscissa is $C$ and the ordinate is $1 /\left(\mathrm{P}_{\mathrm{A}}-\mathrm{P}\right)$. Therefore, the algebraic or time average of the $\mathrm{n}$ terms is given by dividing the area by $n$. Let $\mathrm{P}^{*}$ be the average back pressure obtained by the planimetry, then the above average is expressed by $\left(\mathrm{C}_{n}-\mathrm{C}_{\mathrm{o}}\right)$ / $\mathrm{n}\left(\mathrm{P}_{\mathrm{A}}-\mathrm{P}^{*}\right)$. On the other hand, let $\mathrm{F}_{\mathrm{m}}$ be the time average of the velocity factor during the contact time, there holds the following relation between both the averages of the left and right hand terms of $\operatorname{Eqs}(5)$.

$$
\frac{\mathrm{C}_{\mathrm{n}}-\mathrm{C}_{o}}{\mathrm{P}_{\mathrm{A}}-\mathrm{P}^{*}}=\mathrm{F}_{\mathrm{m}} \cdot \mathrm{T}_{\mathrm{c}}
$$

or

$$
\frac{\mathrm{C}_{\mathrm{n}}-\mathrm{C}_{\mathrm{o}}}{\mathrm{T}_{\mathrm{c}}}=\mathrm{F}_{\mathrm{m}}\left(\mathrm{P}_{\mathrm{A}}-\mathrm{P}^{*}\right) \text {. }
$$

$\mathrm{Eq}(7)$ states that the product of $\mathrm{F}_{\mathrm{m}}$ and $\left(\mathrm{P}_{\mathrm{A}}-\mathrm{P} *\right)$ shows the average concentration increase during the contact time, $T_{c}$.

In FIG. 9 are shown three curves of $\mathrm{O}_{2}$ uptakes by $1 \mathrm{ml}$ red cells in a second, $\mathrm{dC} / \mathrm{dt}$, against the back pressure, when $\mathrm{P}_{\mathrm{A}}=100 \mathrm{mmHg}$. The first curve shows $d C / d t=F_{c}\left(100-P_{c}\right)$, the second curve shows $d C / d t=F_{m}\left(100-P_{c}\right)$, where $F_{m}$ is the time average of $F_{c}$. The third curve is the time average of 
the $\mathrm{O}_{2}$ uptake, $\mathrm{F}_{\mathrm{m}}\left(100-\mathrm{P}^{*}\right)$. Strictly speaking, the $\mathrm{P}^{*}$ must be different from the back pressure, $\mathrm{P}_{\mathrm{m}}$, which has such a certain relation to $\mathrm{F}_{\mathrm{m}}$ as shown by the line of FIG. 8. However, $\mathrm{P}^{*}$ and $\mathrm{P}_{\mathrm{m}}$ agreed practically well with each other as indicated by the intersection of these three curves in FIG. 9.

Originally BoHR's method was introduced for obtaining such a constant velocity factor as the diffusion constant. In that case, the $\mathrm{P}^{*}$ derived by his method is evidently the time average of the back pressure. When the velocity factor is not constant, the $\mathrm{P}^{*}$ calculated is not the time average. However, the $F_{m}$ obtained by using the $P^{*}$ through $\mathrm{Eq}(6)$ is really the time average of the velocity factor. And between the $\mathrm{P}^{*}$ and $\mathrm{F}_{\mathrm{m}}$ there may hold the relation as illustrated by the line in FIG. 8 .

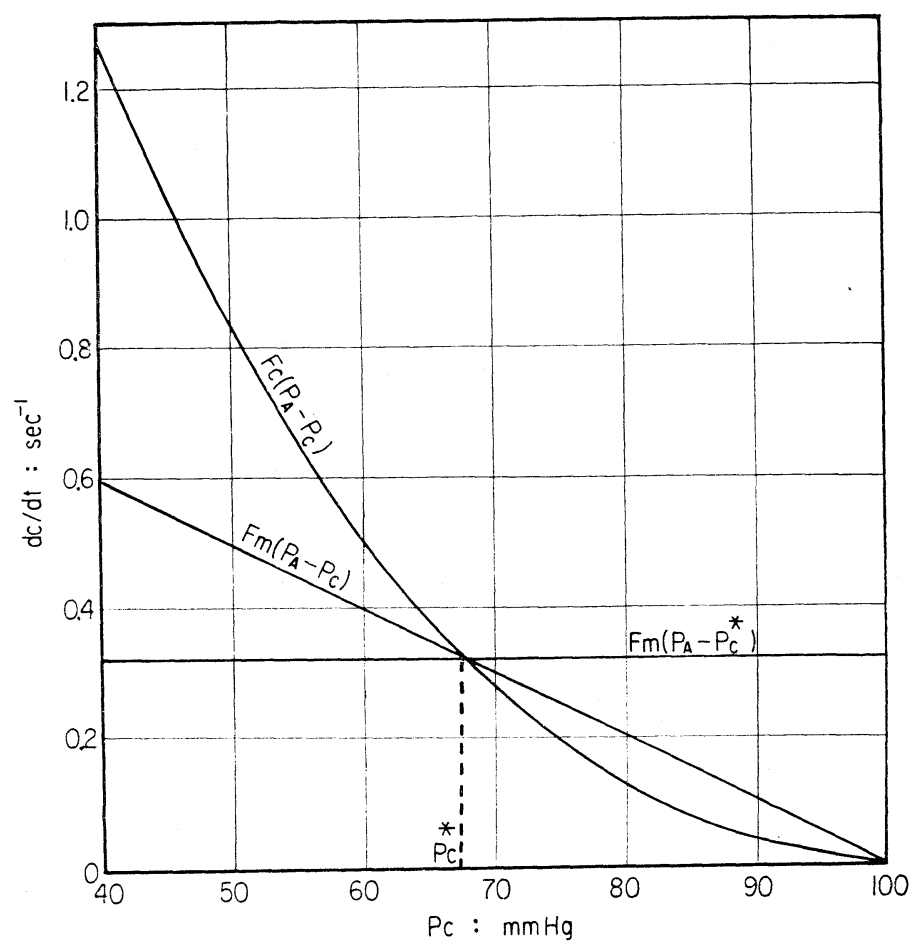

FIG. 9. $\mathrm{O}_{2}$ uptake of $1 \mathrm{ml}$ of red cells in a second, $\mathrm{dC} / \mathrm{dt}$, plotted against the back pressure, where the alveolar $\mathrm{O}_{2}$ tension, $\mathrm{P}_{\mathrm{A}}$, was assumed to be $100 \mathrm{mmHg}$ and the diffusion through the alveolar membrane was disregarded. As $F_{c}$ decreases with increase of $P_{c}$, the real $\mathrm{O}_{2}$ uptake, $\mathrm{F}_{\mathrm{c}}\left(\mathrm{P}_{\mathrm{A}}-\mathrm{P}_{\mathrm{C}}\right)$, decreases exponentially as $P_{c}$ increases. In Bohr's integral, the velocity factor, $F_{c}$, was treated, in the $P_{c}$ range measured, as a constant averaged value, $F_{m}$. Therefore, the $\mathrm{O}_{2}$ uptake was considered to decrease linearly as $\mathrm{P}_{c}$ increased, as shown by $F_{m}\left(P_{A}-P_{c}\right)$. In both cases, the average $O_{2}$ uptake, $F_{m}\left(P_{A}-P^{*}\right)$ agreed well with each other as shown by the intersection of those three curves. 
According to GIBSON and others the total diffusing capacity, $\mathrm{D}_{\mathrm{L}}$, is expressed by the following,

$$
1 / D_{L}=1 / D_{B}+1 / D_{M},
$$

Where $D_{M}$ is the membrane component of the diffusing capacity. On the other hand, according to MochizUKI and FuKUOKA $D_{B}$ is given by $D_{B}=Q \cdot F_{c} \cdot T_{c}$, where $\mathrm{Q}$ is the red cell volume flowing through the total lung capillary in one minute. Thus, if $D_{L}$ 's are measured at two levels of $F_{c}$, the two components of $D_{L}$ may be evaluated by use of $F_{c}$ values shown in FIG. 8.

\section{SUMMARY}

The oxygenation velocities of the red cell and $\mathrm{Hb}$ were studied by means of the rapid flow method with 7 normal subjects. The $\mathrm{S}_{\mathrm{o}_{2}}$ was measured by taking the difference in transmitted light intensities at two wave lengths, so that the influence of the uneven scattering could be excluded fairly well.

The oxygenation velocities were mainly measured over the $\mathrm{S}_{\mathrm{O}_{2}}$ range from 70 to $100 \%$, and they were expressed by the velocity factor. As to the velocity factor of $\mathrm{Hb}, \mathrm{F}_{\mathrm{s}}$, the same result as shown in the preceding paper was confirmed in this study. That is, $\mathrm{F}_{\mathrm{s}}$ was proportional to $\left(100-\mathrm{So}_{\mathrm{s}}\right)^{1.6}$. On the other hand, the velocity factor of the red cell, $F_{c}$, was clarified to be given by

$$
\mathrm{F}_{\mathrm{c}}=\frac{0.025 \cdot \mathrm{F}_{\mathrm{s}}^{1.26}}{0.025+\mathrm{F}_{\mathrm{s}}{ }^{1.26}}
$$

The author wishes to express his thanks to Mr. Takashi ARAI, Mr. Yoshiharu FUJISAWA and Miss Noriko IIDA for their assistance in carrying out the experiments.

\section{REFERENCES}

1) Mochizuki, M., Nakamura, K. And Oyama, Y., Jap. J. Physiol. 15, 519, 1966.

2) Hartridge, H. And Roughton, F. J. W., J. Physiol. 62, 232, 1926.

3) Roughton, F. J. W., Proc. Roy. Soc., B. 111, 1, 1932.

4) Nicolson, P. And Roughton, F. J. W., Proc. Roy. Soc., B. 138, 241, 1951.

5) Roughton, F. J.W., Proc. Roy. Soc., B. 140, 203, 1952.

6) Gibson, Q. H., Kreuzer, F., Meda, E. and Roughton, F. J. W., J. Physiol 129, $65,1955$.

7) Sirs, J.S. and Roughton, F. J. W., J. Appl. Physiol. 18, 158, 1963.

8) Staub, N.C., Bishop, J.M. And Forster, R.E., J. Appl. Physiol. 16, 511, 1961.

9) Millikan, G. A., J. Physiol. 79, 152, 1933.

10) Forster, R. E., Roughton, F. J. W., Kreuzer, F. And Briscoe, W. A., J. Appl. Physiol. 11, 260, 1957.

11) Roughton, F. J.W., And Forster, R. E., J. Appl. Physiol. 11, 290, 1957.

12) Mochizuki, M. And Fukuoka, J., Jap. J. Physiol. 8, 206, 1958.

13) Thews, G., Pfliigers Arch. 265, 138, 1957.

14) Thews, G., ibid. 268, 318, 1959.

15) Bohr, C., Scand. Arch. Physiol., 22, 221, 1909. 